\title{
Vaginal bleeding as a sign of Crimean- Congo hemorrhagic fever infection: a case report
}

\author{
Shohra Qaderi ${ }^{* *} \mathbb{D}$, Hossein Hatami² ${ }^{2}$, Ahmad Murad Omid ${ }^{3}$ and Jalal Sayad ${ }^{3}$
}

\begin{abstract}
Background: Crimean-Congo hemorrhagic fever is a severe vector-borne viral hemorrhagic fever with considerable mortality in humans. This disease is endemic in Afghanistan, and its incidence rate has rapidly increased in recent years. This infection can cause a broad range of hemorrhage manifestations including epistaxis, petechial or purpuric rashes, hematemesis, and melena; however, vaginal bleeding is also reported as a rare manifestation.

Case presentation: We report the case of a previously healthy 30-year-old Afghan female of shepherding occupation, with a sudden onset of fever, generalized body pain, epistaxis, and vaginal bleeding. She was admitted to the hospital after 7 days of symptom manifestation, with predominant signs being high fever, vaginal bleeding, and elevated liver enzymes. The serological test result for Crimean-Congo hemorrhagic fever was positive. She was treated with oral ribavirin and discharged with normal parameters.
\end{abstract}

Conclusions: People in high-risk professions in endemic areas should be informed that vaginal bleeding is a serious symptom and requires immediate action and, therefore, might be attributed to nongynecologic disorders.

Keywords: Uterine bleeding, Afghanistan, Crimean-Congo hemorrhagic fever (CCHF)

\section{Introduction}

Crimean-Congo hemorrhagic fever (CCHF), is an acute, severe vector-borne viral hemorrhagic fever with considerable mortality in humans. The causative agent is the genus Nairovirus within the family of Bunyaviridae [1, 2]. Human CCHF is characterized by a sudden onset of fever, headache, dizziness, nausea, weakness, irritability, and severe limb and loin pain, which has shown a wide range of severity, from mild, nonspecific febrile illness to shock and death. The hemorrhagic symptoms include petechiae and/or ecchymosis spreading over the chest, abdomen, and rest of the body; sometimes large purpuric areas are reported. In severe cases, bleeding from the

\footnotetext{
*Correspondence: Shohra_qaderi@yahoo.com

${ }^{1}$ Student Research Committee, Shahid Beheshti University of Medical Sciences, Tehran, Iran

Full list of author information is available at the end of the article
}

gums, nose, lung, uterus, and intestine are reported and can progress to multiorgan failure [3, 4]. The case fatality rate is about $10-40 \%$ [5]. The disease is endemic in more than 30 countries worldwide. In recent years, the incidence of CCHF has increased rapidly in the countries of World Health Organization Eastern Mediterranean Region (WHO EMR), with sporadic human cases and outbreak of CCHF being reported for a number of countries in the region [6,7]. Afghanistan is located in the region in which Hyalomma ticks are quite common, and experiences the disease regularly; an average of 5-50 human cases are reported every year in the country. The highest numbers of cases were reported in Kabul and Herat provinces, which share borders with Pakistan and Iran, where livestock movement across borders is not controlled. According to the latest related report in 2017, the total number of cases reported in Afghanistan was 245 [ $48 \%$ case fatality rate (CFR)], with one case of original author(s) and the source, provide a link to the Creative Commons licence, and indicate if changes were made. The images or other third party material in this article are included in the article's Creative Commons licence, unless indicated otherwise in a credit line to the material. If material is not included in the article's Creative Commons licence and your intended use is not permitted by statutory regulation or exceeds the permitted use, you will need to obtain permission directly from the copyright holder. To view a copy of this licence, visit http://creativecommons.org/licenses/by/4.0/. The Creative Commons Public Domain Dedication waiver (http://creativeco mmons.org/publicdomain/zero/1.0/) applies to the data made available in this article, unless otherwise stated in a credit line to the data. 
vaginal bleeding due to $\mathrm{CCHF}[8,9]$. Thus, in this case report, we present the epidemiological, clinical, and paraclinical features of Crimean-Congo hemorrhagic fever in patients with vaginal bleeding as a rare and nongynecological symptom who were admitted to Antani Hospital in Kabul, Afghanistan in 2018.

\section{Case presentation}

On the evening of 5 May $2018(T=0)$, a non-Kabul resident, 30-year-old Afghan single female was admitted to Kabul Antani Hospital because of fever, pain, hemorrhage (petechia, epistaxis, and uterine bleeding), and vomiting. The patient reported sudden-onset fever and generalized body ache 1 week prior to hospital presentation $(T=7)$. Two days later, the patient had nausea and vomiting regardless of having meals; however, she had not been brought to any health centers. One day later $(T=3)$, she presented epistaxis and vaginal bleeding [last menstrual period (LMP) was on 20 April]. Then, she was brought to the hospital and admitted to the CCHF ward of Kabul Antani Hospital. She denied history of travel, tick bite, and sick contacts; she had no prior medical conditions or medication use. She did not consume alcohol or smoke. She lived in a rural area, and all her family members worked as shepherds. At the time of admission, pulse rate was 92 beats per minute, blood pressure $70 / 50 \mathrm{mmHg}$, and respiratory rate 20 breaths per minute, and she had a temperature of $38{ }^{\circ} \mathrm{C}$. Physical examination findings included pallor, with petechiae and uterine bleeding (without gynecological history). The patient appeared confused on examination. The patient was anemic with a remarkably low platelet count $10 \times 10^{3} / \mu \mathrm{L}$. The levels of aspartate transaminase (AST) and alanine aminotransferase (ALT) were $1921 \mathrm{U} / \mathrm{L}$ and $1318 \mathrm{U} / \mathrm{L}$, respectively, alkaline phosphatase (ALP) was $796 \mathrm{U} / \mathrm{L}$, and other laboratory test results are presented in Table 1. CCHF virus was detected from a blood sample drawn on the fourth day with a positive enzyme-linked immunosorbent assay (ELISA) test for specific CCHF immunoglobulin $M$ (IgM) antibodies by the National Laboratory of Public Health Ministry. Results of hepatitis B testing (hepatitis B surface antigen, hepatitis B core IgG antibody) and hepatitis $\mathrm{C}$ testing (the $\mathrm{HCV}$ antibody test) were negative. Owing to financial issues, some serological tests such as Leptospira, Salmonella, Toxoplasma species, and Lyme disease were not performed. In the CCHF department of the hospital, the patient had been prescribed oral ribavirin as recommended by the World Health Organization (WHO), and supportive therapy was given as presented in Table 2. The patient was hospitalized for a total of 8 days. Details of the development of vital signs over the course of receiving ribavirin during her hospitalization are presented in Table 3. As patients
Table 1 Laboratory data*

\begin{tabular}{|c|c|c|}
\hline Variables & Reference range & Hospital range \\
\hline \multicolumn{3}{|l|}{ Blood } \\
\hline Hemoglobin (g/dl) & $12-15$ & 10 \\
\hline Hematocrit (\%) & $36-45$ & 38.4 \\
\hline White-cell count (per $\mathrm{mm}^{3}$ ) & $4-11$ & 2300 \\
\hline Platelet count (per mm³) & $150-400$ & 10,000 \\
\hline Alanine aminotransferase $(\mathrm{U} / \mathrm{L})$ & $0-40$ & 1318 \\
\hline Aspartate aminotransferase $(\mathrm{U} / \mathrm{L})$ & $0-40$ & 1921 \\
\hline Total bilirubin (mg/dl) & $<1.2$ & 2.2 \\
\hline Direct bilirubin (mg/dl) & & 1 \\
\hline Indirect bilirubin $(\mathrm{mg} / \mathrm{dl})^{\beta}$ & & 1.2 \\
\hline $\begin{array}{l}\text { Prothrombin-time international } \\
\text { normalized ratio }\end{array}$ & $0.9-1.1$ & 3 \\
\hline \multicolumn{3}{|l|}{ Urine } \\
\hline Color & Yellow & Dark \\
\hline Clarity & Clear & \\
\hline Specific gravity & 1.033 & 1.000 \\
\hline $\mathrm{pH}$ & 7 & 7.2 \\
\hline Protein & & $2+$ \\
\hline White cells per high-power field & & $2+$ \\
\hline Red cells per high-power field & & $3+$ \\
\hline
\end{tabular}

*All these tests were carried out in Antani's hospital laboratory. $\mathrm{mg} / \mathrm{dl}$ : Milligram Per Decilitre

${ }^{\beta}$ We obtained indirect bilirubin via total bilirubin - direct bilirubin

are not normally followed up in governmental hospitals of Afghanistan, information about her condition after discharge was not available.

\section{Discussion}

Here, we presented the case of a woman working as a shepherd who had uterine bleeding as a rare and nongynecological sign of CCHF that led to 8 days of hospitalization. Crimean-Congo hemorrhagic fever is a severe tick-borne disease with a wide range of geographical distribution. The disease is endemic over a wide geographic area, mainly in Southern Europe, Africa, the Middle East, and Asia [3]. Afghanistan is located in the endemic region of this disease and experiences the disease regularly, about 5-50 cases every year, but the majority of cases occur around Eid-Adha (sacrifice feast in Islam) in which there is increased human contact with livestock due to sacrificial rituals/norms. Residence in rural area and close contact with livestock are shown to be more common in CCHF cases, both of which were the case in our patient. These groups should be considered as susceptible/vulnerable to CCHF infection. There is little information about the pathogenesis of the infection, but the interaction between the virus and host cells (mainly endothelial cells and immune cells) is most likely 
Table 2 Treatment*

\begin{tabular}{|c|c|c|c|c|c|c|c|c|c|}
\hline Intervention & Dose/frequency & First day & Second day & Third day & Fourth day & Fifth day & Sixth day & Seventh day & Eighth day \\
\hline Pantoprazole & $40 \mathrm{mg}$ once & Yes & Yes & Yes & Yes & Yes & No & No & No \\
\hline Ringer lactate & 1000 cc once & Yes & Yes & Yes & Yes & Yes & Yes & Yes & Yes \\
\hline Cefotaxime & $2 \mathrm{~g}$ three times daily & Yes & Yes & Yes & Yes & Yes & Yes & Yes & Yes \\
\hline Ribavirin & 2000 mg/once & Yes & Yes & Yes & Yes & Yes & Yes & Yes & Yes \\
\hline Platelet mass & 400 cc once & Yes & Yes & Yes & Yes & Yes & Yes & Yes & Yes \\
\hline
\end{tabular}

*Treatment received by patient over 8 days of hospitalization. Ribavirin $400 \mathrm{mg}$ daily for two more 2 days and cefotaxime $1 \mathrm{~g}$ daily were prescribed as home treatment

Table 3 Daily vital signs

\begin{tabular}{|c|c|c|c|c|c|c|c|c|}
\hline Days of admission & First & Second & Third & Fourth & Fifth & Sixth & Seventh & Eighth \\
\hline $\begin{array}{l}\text { Blood pressure (systole/ } \\
\text { diastole, } \mathrm{mmHg} \text { ) }\end{array}$ & $70 / 50$ & $87 / 50$ & $100 / 60$ & $110 / 70$ & $100 / 60$ & $100 / 70$ & $110 / 60$ & $110 / 70$ \\
\hline RR (per minute) & 20 & 20 & 20 & 20 & 22 & 20 & 22 & 20 \\
\hline PR (per minute) & 78 & 92 & 88 & 82 & 80 & 84 & 74 & 74 \\
\hline $\mathrm{T}\left({ }^{\circ} \mathrm{C}\right)$ & 38 & 37.6 & 37.4 & 37.2 & 37.3 & 37 & 37 & 37 \\
\hline
\end{tabular}

$R R$ respiratory rate, $P R$ pulse rate. $T$ temperature

responsible for the pathogenesis. There are two theories about CCHF pathogenesis: the first is that the virus interacts with endothelial cells, and the latter is that the virus interacts indirectly with immune cells, which results in the release of mediators [10]. Hemorrhage as a main sign of CCHF has two mechanisms: the first is through a direct effect on hemostasis cells such as thrombocytes and endothelial cells, and the second is through immune and inflammatory pathways that lead to cellular damage. The liver is the main site of CCHF virus replication. During replication, the virus is able to induce cytopathic effects, including hepatocyte necrosis and apoptosis, Kupffer cell hyperplasia, and fatty changes [6-10]. The majority of Afghanistan CCHF cases visited hospitals at the hemorrhagic phase of the infection, and this delay reduces the efficacy of ribavirin and leads to more serious health complications $[8,11]$. This febrile, hemorrhage disease can cause a broad range of hemorrhagic manifestations including petechiae and/or ecchymosis spreading over the chest, abdomen, and rest of the body; sometimes large purpuric areas are reported. In severe cases, bleeding from the gums, nose, lung, uterus, and intestine are reported and can progress to multiorgan failure; however, vaginal bleeding is a rare manifestation of CCHF infection. According to previous studies, the hemorrhagic phase of the infection starts between the third and sixth day of symptom onset; in our patient, bleeding started on day 4 [6]. Statistical significance has not been reported for age, gender, and tick contact, regarding fatality to the infection [14]. Hemorrhage has been reported in all fatal cases, and the presence of bleeding is the most important predictive factor of fatality. Epistasis is the most common type of bleeding, and bleeding in more than one system has been seen in patients who died, but it is difficult to determine which types of hemorrhages are associated with fatality of this infection [12, 14]. Previous studies investigated vaginal bleeding as a sign of CCHF infection [9-14]. Thrombocytopenia, leukopenia, and elevation of AST, ALT, and international normalized ratio (INR) are some typical hematological changes in a patient with CCHF infection, which were seen in our case. The elevation of AST and INR and thrombocytopenia were found to be predictors of fatality/mortality [14]. This case report, however, puts an emphasis on the importance of vaginal bleeding being considered a matter of urgency that requires immediate action and, therefore, might be attributed to nongynecologic disorders.

\section{Conclusion}

$\mathrm{CCHF}$ is a serious public health problem/threat that is endemic in Afghanistan. This infection can cause a wide range of hemorrhage manifestations of which vaginal bleeding is a serious symptom that requires immediate action. Vaginal bleeding is an uncommon symptom of this disease and, therefore, might be attributed to nongynecologic disorders. Low platelet count, low level of white blood cells, and vaginal bleeding, especially in endemic areas, could suggest CCHF infection.

\section{Abbreviation}

CCHF: Crimean-Congo hemorrhagic fever. 


\section{Acknowledgments}

The authors would like to thank the reviewers for their insightful comments.

\section{Authors' contributions}

SQ carried out the study design and drafted the manuscript. $\mathrm{HH}$ coordinated the study, drafted the manuscript, and helped us in Afghanistan determine what information must be obtained from the patient and laboratory results. JS and AMO had direct contact with the patient, were responsible for patient observation, and reported the clinical signs and symptoms. All authors read and approved the final manuscripts.

\section{Funding}

Not applicable.

\section{Availability of data and materials}

Not applicable. No new data generated.

\section{Declarations}

Ethics approval and consent to participate

Not applicable.

\section{Consent for publication}

Written informed consent was obtained from the patient for the publication of this case report. A copy of the written consent is available for review by the Editor-in-Chief of this journal.

\section{Competing interests}

There is no conflict of interest.

\section{Author details}

${ }^{1}$ Student Research Committee, Shahid Beheshti University of Medical Sciences, Tehran, Iran. ${ }^{2}$ Center of Public Health, Environmental and Occupational Hazards Control, Shahid Beheshti University of Medical Science, Tehran, Iran. ${ }^{3}$ Crimean-Congo Hemorrhagic Ward, Department of Communicable Disease, Kabul Antani Hospital, Ministry of Public Health, Kabul, Afghanistan.

Received: 21 February 2020 Accepted: 1 February 2022

Published online: 22 February 2022

\section{References}

1. Wölfel R, Paweska JT, Petersen $N$, et al. Virus detection and monitoring of viral load in Crimean-Congo hemorrhagic fever virus patients. Emerg Infect Dis. 2007:13(7):1097.

2. Jabbari A, Tabasi S, Abbasi A, et al. Crimean-Congo hemorrhagic fever: treatment and control strategy in admitted patients. Caspian J Intern Med. 2012;3(2):443.

3. Hoogstraal $H$. The epidemiology of tick-borne Crimean-Congo hemorrhagic fever in Asia, Europe, and Africa. J Med Entomol. 1979;15(4):307-417.

4. Heymann DL. Control of Communicable Diseases Manual, An official report of the American Public Health Association; 19th Edition, 2008.

5. Kuljić-Kapulica N. Emerging diseases: Crimean-Congo hemorrhagic fever. Med Pregl. 2004;57(9-10):453-6.

6. Ergönül Ö. Crimean-Congo haemorrhagic fever. Lancet Infect Dis. 2006;6(4):203-14.

7. Papa A, Weber F, Hewson R, et al. Meeting report: first international conference on Crimean-Congo hemorrhagic fever. Antiviral Res. 2015:120:57-65.

8. Hatami H, Qaderi S, Omid AM. Investigation of Crimean-Congo hemorrhagic fever in patients admitted in Antani Hospital, Kabul, Afghanistan, 2017-2018. Int J Prev Med. 2019;10:117.

9. Sahak MN, Arifi F, Saeedzai SA. Descriptive epidemiology of Crimean-Congo Hemorrhagic Fever (CCHF) in Afghanistan: reported cases to National Surveillance System, 2016-2018. Int J Infect Dis. 2019;1 (88):135-40.

10. Akıncı E, Bodur H, Leblebicioglu H. Pathogenesis of Crimean-Congo hemorrhagic fever. Vector-Borne Zoonotic Dis. 2013;13(7):429-37.
11. Qaderi S, Mardani M, Shah A, Shah J, Bazgir N, Sayad J, Ghandchi E, Samsami M, Bagherpour JZ. Crimean-Congo Hemorrhagic Fever (CCHF) in Afghanistan: a retrospective single center study. Int J Infect Dis. 2021;1(103):323-8.

12. Ozbey SB, Kader Ç, Erbay A, et al. Early use of ribavirin is beneficial in Crimean-Congo hemorrhagic fever. Vector-Borne Zoonotic Dis. 2014;14(4):300-2.

13. Muco E, Como N, Bino S, et al. Crimean-Congo hemorrhagic fever with hepatic impairment and vaginal hemorrhage: a case report. J Med Case Rep. 2018;12(1):118.

14. Ozturk B, Tutuncu E, Kuscu F, Gurbuz Y, Sencan I, Tuzun H. Evaluation of factors predictive of the prognosis in Crimean-Congo hemorrhagic fever: new suggestions. Int J Infect Dis. 2012;16(2):e89-93.

\section{Publisher's Note}

Springer Nature remains neutral with regard to jurisdictional claims in published maps and institutional affiliations.
Ready to submit your research? Choose BMC and benefit from:

- fast, convenient online submission

- thorough peer review by experienced researchers in your field

- rapid publication on acceptance

- support for research data, including large and complex data types

- gold Open Access which fosters wider collaboration and increased citations

- maximum visibility for your research: over $100 \mathrm{M}$ website views per year

At BMC, research is always in progress.

Learn more biomedcentral.com/submissions 